4

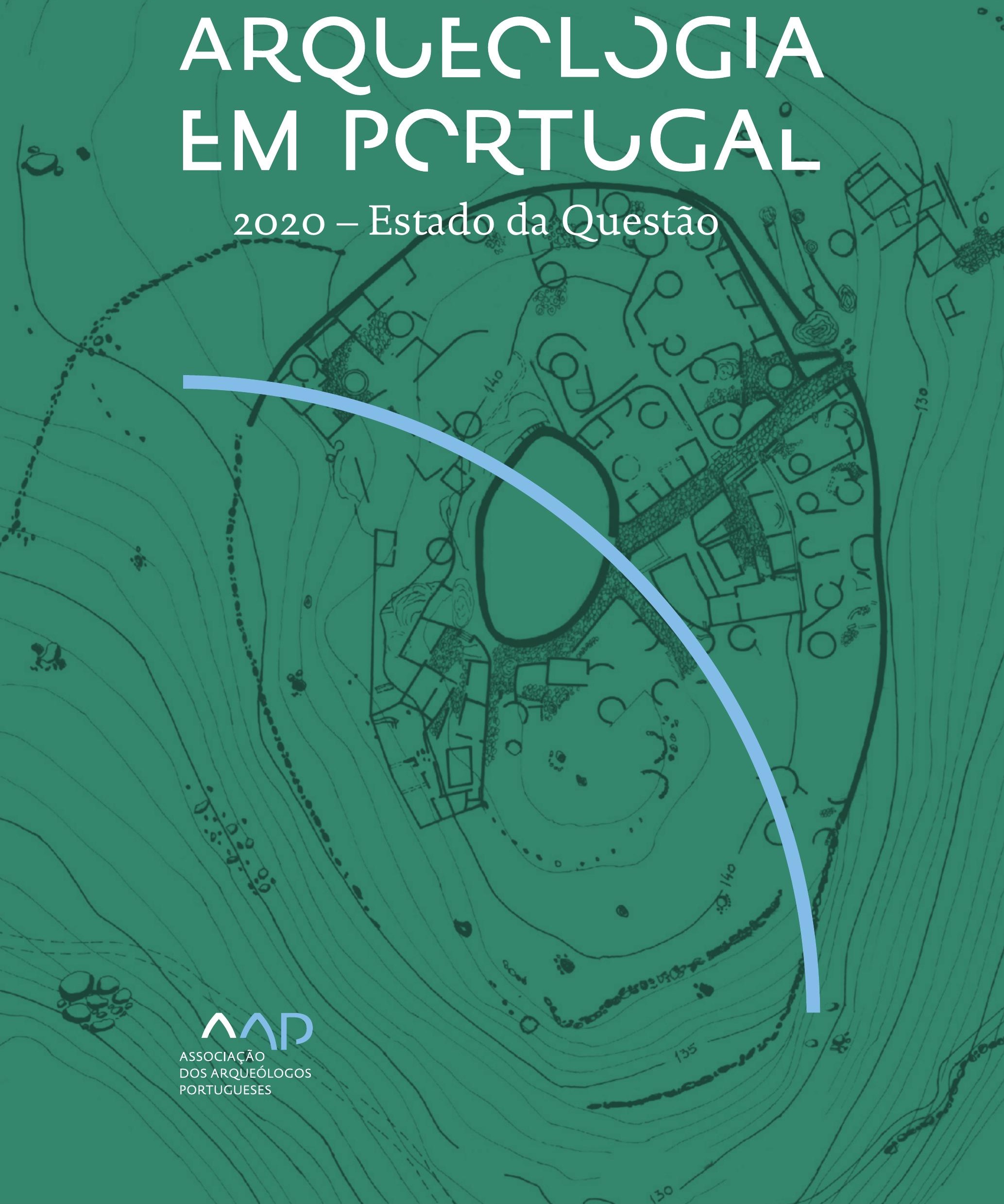


Coordenação editorial: José Morais Arnaud, César Neves e Andrea Martins Design gráfico: Flatland Design

AAP - ISBN: 978-972-9451-89-8

CITCEM - ISBN: 978-989-8970-25-1

Associação dos Arqueólogos Portugueses e CITCEM

Lisboa, 2020

O conteúdo dos artigos é da inteira responsabilidade dos autores. Sendo assim a Associação dos Arqueólogos Portugueses declina qualquer responsabilidade por eventuais equívocos ou questões de ordem ética e legal.

Desenho de capa:

Planta do castro de Monte Mozinho (Museu Municipal de Penafiel).

\section{$\hat{\wedge} \mathrm{P}$}

DOS ARQUEÓLOGOS PORTUGUESES

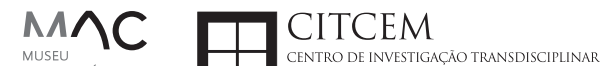
MUSEU
ARQUELLÓGICO
DO CARMO
U.PORTO

FLUP FACULDADE DE LETRAS
UNIVERSIDADE DO PORTO

Apoio

EC para a Ciência 


\section{Índice}

15 Prefácio

José Morais Arnaud

\section{Historiografia e Teoria}

17 Território, comunidade, memória e emoção: a contribuição da história da arqueologia (algumas primeiras e breves reflexões)

Ana Cristina Martins

25 Como descolonizar a arqueologia portuguesa?

Rui Gomes Coelho

41 Arqueologia e Modernidade: uma revisitação pessoal e breve de alguns aspetos da obra homónima de Julian Thomas de 2004

Vítor Oliveira Jorge

57 Dados para a História das Mulheres na Arqueologia portuguesa, dos finais do século XIX aos inícios do século XX: números, nomes e tabelas

Filipa Dimas / Mariana Diniz

73 Retractos da arqueologia portuguesa na imprensa: (in)visibilidades no feminino

Catarina Costeira / Elsa Luís

85 Arqueologia e Arqueólogos no Norte de Portugal Jacinta Bugalhão

101 Vieira Guimarães (1864-1939) e a arqueologia em Tomar: uma abordagem sobre o território e as gentes

João Amendoeira Peixoto / Ana Cristina Martins

115 Os memoráveis? A arqueologia algarvia na imprensa nacional e regional na presente centúria (2001-2019): características, visões do(s) passado(s) e a arqueologia

enquanto marca

Frederico Agosto / João Silva

129 A Evolução da Arqueologia Urbana e a Valorização Patrimonial no Barlavento Algarvio: Os casos de Portimão e Silves

Artur Mateus / Diogo Varandas / Rafael Boavida

\section{Gestão, Valorização e Salvaguarda do Património}

145 O Caderno Reivindicativo e as condições de trabalho em Arqueologia Miguel Rocha / Liliana Matias Carvalho / Regis Barbosa / Mauro Correia / Sara Simões / Jacinta Bugalhão / Sara Brito / Liliana Veríssimo Carvalho / Richard Peace / Pedro Peça / Cézer Santos

155 Os Estudos de Impacte Patrimonial como elemento para uma estratégia sustentável de minimização de impactes no âmbito de reconversões agrícolas Tiago do Pereiro

165 Salvaguarda de Património arqueológico em operações florestais: gestão e sensibilização Filipa Bragança / Gertrudes Zambujo / Sandra Lourenço / Belém Paiva / Carlos Banha / Frederico Tatá Regala / Helena Moura / Jacinta Bugalhão / João Marques / José Correia / Pedro Faria / Samuel Melro

179 Os valores do Património: uma investigação sobre os Sítios Pré-históricos de Arte Rupestre do Vale do Rio Côa e de Siega Verde José Paulo Francisco 
189 Conjugando recursos arqueológicos e naturais para potenciar as visitas ao Geoparque Litoral de Viana do Castelo (Noroeste de Portugal)

Hugo A. Sampaio / Ana M.S. Bettencourt / Susana Marinho / Ricardo Carvalhido

203 Áreas de Potencial Arqueológico na Região do Médio Tejo: Modelo Espacial Preditivo Rita Ferreira Anastácio / Ana Filipa Martins / Luiz Oosterbeek

223 Património Arqueológico e Gestão Territorial: O contributo da Arqueologia para a revisão do PDM de Avis

Ana Cristina Ribeiro

237 A coleção arqueológica do extinto Museu Municipal do Porto - Origens, Percursos e Estudos

Sónia Couto

251 Valpaços - uma nova carta arqueológica

Pedro Pereira / Maria de Fátima Casares Machado

263 Arqueologia na Cidade de Peniche

Adriano Constantino / Luís Rendeiro

273 Arqueologia Urbana: a cidade de Lagos como caso de Estudo Cátia Neto

285 Estratégias de promoção do património cultural subaquático nos Açores. O caso da ilha do Faial

José Luís Neto / José Bettencourt / Luís Borges / Pedro Parreira

297 Carta Arqueológica da Cidade Velha: Uma primeira abordagem

Jaylson Monteiro / Nireide Tavares / Sara da Veiga / Claudino Ramos / Edson Brito /

Carlos Carvalho / Francisco Moreira / Adalberto Tavares

311 Antropologia Virtual: novas metodologias para a análise morfológica e funcional Ricardo Miguel Godinho / Célia Gonçalves

\section{Didáctica da Arqueologia}

327 Como os projetos de Arqueologia podem contribuir para uma comunidade culturalmente mais consciente Alexandra Figueiredo / Claúdio Monteiro / Adolfo Silveira / Ricardo Lopes

337 Educação Patrimonial - Um cidadão esclarecido é um cidadão ativo! Ana Paula Almeida

351 A aproximação da Arqueologia à sala de aula: um caso de estudo no $3^{\circ}$ ciclo do Ensino Básico Luís Serrão Gil

363 Arqueologia 3.o - Pensar e comunicar a Arqueologia para um futuro sustentável Mónica Rolo

377 “Conversa de Arqueólogos" - Divulgar a Arqueologia em tempos de Pandemia Diogo Teixeira Dias

389 Escola Profissional de Arqueologia: desafios e oportunidades Susana Nunes / Dulcineia Pinto / Júlia Silva / Ana Mascarenhas

399 Os Museus de Arqueologia e os Jovens: a oferta educativa para o público adolescente Beatriz Correia Barata / Leonor Medeiros

411 O museu universitário como mediador entre a ciência e a sociedade: o exemplo da secção de arqueologia no Museu de História Natural e da Ciência da Universidade do Porto (MHNC-UP)

Rita Gaspar 
421 Museu de Lanifícios: Real Fábrica de Panos. Atividades no âmbito da Arqueologia Beatriz Correia Barata / Rita Salvado

427 Arqueologia Pública e o caso da localidade da Mata (Torres Novas) Cláudia Manso / Ana Rita Ferreira / Cristiana Ferreira / Vanessa Cardoso Antunes

431 Do sítio arqueológico ao museu: um percurso (também) didático Lídia Fernandes

447 Estão todos convidados para a Festa! E para dançar também... O projecto do Serviço Educativo do Museu Arqueológico do Carmo na $5^{\underline{a}}$ Edição da Festa da Arqueologia Rita Pires dos Santos

459 O “Clã de Carenque”, um projeto didático de arqueologia Eduardo Gonzalez Rocha

469 Mediação cultural: peixe que puxa carroça nas Ruínas Romanas de Troia Inês Vaz Pinto / Ana Patrícia Magalhães / Patrícia Brum / Filipa Santos

481 Didática Arqueológica, experiências do Projeto Mértola Vila Museu Maria de Fátima Palma / Clara Rodrigues / Susana Gómez / Lígia Rafael

\section{Arte Rupestre}

497 Os inventários de arte rupestre em Portugal Mila Simões de Abreu

513 O projeto FIRST-ART - conservação, documentação e gestão das primeiras manifestações de arte rupestre no Sudoeste da Península Ibérica: as grutas do Escoural e Maltravieso Sara Garcês / Hipólito Collado / José Julio García Arranz / Luiz Oosterbeek / António Carlos Silva / Pierluigi Rosina / Hugo Gomes / Anabela Borralheiro Pereira / George Nash / Esmeralda Gomes / Nelson Almeida / Carlos Carpetudo

523 Trabalhos de documentação de arte paleolítica realizados no âmbito do projeto PalæoCôa André Tomás Santos / António Fernando Barbosa / Luís Luís / Marcelo Silvestre / Thierry Aubry

537 Imagens fantasmagóricas, silhuetas elusivas: as figuras humanas na arte do Paleolítico Superior da região do Côa Mário Reis

$55^{1}$ Os motivos zoomórficos representados nas placas de tear de Vila Nova de São Pedro (Azambuja, Portugal) Andrea Martins / César Neves / José M. Arnaud / Mariana Diniz

571 Arte Rupestre do Monte de Góios (Lanhelas, Caminha). Síntese dos resultados dos trabalhos efectuados em 2007-2009 Mário Varela Gomes

599 Gravuras rupestres de barquiformes no Monte de S. Romão, Guimarães, Noroeste de Portugal Daniela Cardoso

613 Círculos segmentados gravados na Bacia do Rio Lima (Noroeste de Portugal): contributos para o seu estudo Diogo Marinho / Ana M.S. Bettencourt / Hugo Aluai Sampaio

631 Equídeos gravados no curso inferior do Rio Mouro, Monção (NW Portugal). Análise preliminar Coutinho, L.M. / Bettencourt, A.M.S / Sampaio, Hugo A.S

645 Paletas na Arte Rupestre do Noroeste de Portugal. Inventário preliminar Bruna Sousa Afonso / Ana M. S. Bettencourt / Hugo A. Sampaio 


\section{Pré-História}

661 O projeto Miño/Minho: balanço de quatro anos de trabalhos arqueológicos Sérgio Monteiro-Rodrigues / João Pedro Cunha-Ribeiro / Eduardo Méndez-Quintas / Carlos Ferreira / Pedro Xavier / José Meireles / Alberto Gomes / Manuel Santonja / Alfredo Pérez-González

677 A ocupação paleolítica da margem esquerda do Baixo Minho: a indústria lítica do sítio de Pedreiras 2 (Monção, Portugal) e a sua integração no contexto regional Carlos Ferreira / João Pedro Cunha-Ribeiro / Sérgio Monteiro-Rodrigues / Eduardo Méndez-Quintas / Pedro Xavier / José Meireles / Alberto Gomes / Manuel Santonja / Alfredo Pérez-González

693 O sítio acheulense do Plistocénico médio da Gruta da Aroeira Joan Daura / Montserrat Sanz / Filipa Rodrigues / Pedro Souto / João Zilhão

703 As sociedades neandertais no Barlavento algarvio: modelos preditivos com recurso aos SIG

Daniela Maio

715 A utilização de quartzo durante o Paleolítico Superior no território dos vales dos rios Vouga e Côa

Cristina Gameiro / Thierry Aubry / Bárbara Costa / Sérgio Gomes / Luís Luís / Carmen Manzano / André Tomás Santos

733 Uma perspetiva diacrónica da ocupação do concheiro do Cabeço da Amoreira (Muge, Portugal) a partir da tecnologia lítica Joana Belmiro / João Cascalheira / Célia Gonçalves

745 Novos dados sobre a Pré-história Antiga no concelho de Palmela. A intervenção arqueológica no sítio do Poceirão I

Michelle Teixeira Santos

757 Problemas em torno de Datas Absolutas Pré-Históricas no Norte do Alentejo Jorge de Oliveira

771 Povoamento pré-histórico nas áreas montanhosas do NO de Portugal: o Abrigo 1 de Vale de Cerdeira Pedro Xavier / José Meireles / Carlos Alves

783 Apreciação do povoamento do Neolítico Inicial na Baixa Bacia do Douro. A Lavra I (Serra da Aboboreira) como caso de estudo Maria de Jesus Sanches

797 O Processo de Neolitização na Plataforma do Mondego: os dados do Sector C do Outeiro dos Castelos de Beijós (Carregal do Sal)

João Carlos de Senna-Martinez / José Manuel Quintã Ventura / Andreia Carvalho / Cíntia Maurício

823 Novos trabalhos na Lapa da Bugalheira (Almonda, Torres Novas) Filipa Rodrigues / Pedro Souto / Artur Ferreira / Alexandre Varanda / Luís Gomes / Helena Gomes / João Zilhão

837 A pedra polida e afeiçoada do sítio do Neolítico médio da Moita do Ourives (Benavente, Portugal)

César Neves

857 Casal do Outeiro (Encarnação, Mafra): novos contributos para o conhecimento do povoamento do Neolítico final na Península de Lisboa.

Cátia Delicado / Carlos Maneira e Costa / Marta Miranda / Ana Catarina Sousa

873 Stresse infantil, morbilidade e mortalidade no sítio arqueológico do Neolítico Final/ Calcolítico ( $4^{\circ}$ e $3^{\circ}$ milénio a.C.) do Monte do Carrascal 2 (Ferreira do Alentejo, Beja) Liliana Matias de Carvalho / Sofia N. Wasterlain 
885 Come together: O Conjunto Megalítico das Motas (Monção, Viana do Castelo) e as expressões Campaniformes do Alto Minho Ana Catarina Basílio / Rui Ramos

899 Trabalhos arqueológicos no sítio Calcolítico da Pedreira do Poio Carla Magalhães / João Muralha / Mário Reis / António Batarda Fernandes

913 O sítio arqueológico de Castanheiro do Vento. Da arquitectura do sítio à arquitectura de um território João Muralha Cardoso

925 Estudo zooarqueológico das faunas do Calcolítico final de Vila Nova de São Pedro (Azambuja, Portugal): Campanhas de 2017 e 2018 Cleia Detry / Ana Catarina Francisco / Mariana Diniz / Andrea Martins / César Neves / José Morais Arnaud

943 As faunas depositadas no Museu Arqueológico do Carmo provenientes de Vila Nova de São Pedro (Azambuja): as campanhas de 1937 a 1967 Ana Catarina Francisco / Cleia Detry / César Neves / Andrea Martins / Mariana Diniz / José Morais Arnaud

959 Análise funcional de material lítico em sílex do castro de Vila Nova de S. Pedro (Azambuja, Portugal): uma primeira abordagem Rafael Lima

971 O recinto da Folha do Ouro 1 (Serpa) no contexto dos recintos de fossos calcolíticos alentejanos

António Carlos Valera / Tiago do Pereiro / Pedro Valério / António M. Monge Soares

\section{Proto-História}

987 Produção de sal marinho na Idade do Bronze do noroeste Português. Alguns dados para uma reflexão

Ana M. S. Bettencourt / Sara Luz / Nuno Oliveira / Pedro P. Simões / Maria Isabel C. Alves / Emílio Abad-Vidal

1001 A estátua-menir do Pedrão ou de São Bartolomeu do Mar (Esposende, noroeste de Portugal) no contexto arqueológico da fachada costeira de entre os rios Neiva e Cávado Ana M. S. Bettencourt / Manuel Santos-Estévez / Pedro Pimenta Simões / Luís Gonçalves

1015 O Castro do Muro (Vandoma/Baltar, Paredes) - notas para uma biografia de ocupação da Idade do Bronze à Idade Média

Maria Antónia D. Silva / Ana M. S. Bettencourt / António Manuel S. P. Silva / Natália Félix

1031 Do Bronze Final à Idade Média - continuidades e hiatos na ocupação de Povoados em Oliveira de Azeméis João Tiago Tavares / Adriaan de Man

1041 As faunas do final da Idade do Bronze no Sul de Portugal: leituras desde o Outeiro do Circo (Beja)

Nelson J. Almeida / Íris Dias / Cleia Detry / Eduardo Porfírio / Miguel Serra

1055 A Espada do Monte das Oliveiras (Serpa) - uma arma do Bronze Pleno do Sudoeste Rui M. G. Monge Soares / Pedro Valério / Mariana Nabais / António M. Monge Soares

1065 São Julião da Branca (Albergaria-a-Velha) - Investigação e valorização de um povoado do Bronze Final

António Manuel S. P. Silva / Paulo A. P. Lemos / Sara Almeida e Silva / Edite Martins de Sá

1083 Do castro de S. João ao Mosteiro de Santa Clara: notícia de uma intervenção arqueológica, em Vila do Conde Rui Pinheiro 
1095 O castro de Ovil (Espinho), um quarto de século de investigação - resultados e questões em aberto

Jorge Fernando Salvador / António Manuel S. P. Silva

1111 O Castro de Salreu (Estarreja), um povoado proto-histórico no litoral do Entre Douro e Vouga

Sara Almeida e Silva / António Manuel S. P. Silva / Paulo A. P. Lemos / Edite Martins de Sá

1127 Castro de Nossa Senhora das Necessidades (Sernancelhe): uma primeira análise artefactual Telma Susana O. Ribeiro

${ }_{1141}$ A cividade de Bagunte. O estado atual da investigação Pedro Brochado de Almeida

1153 Zoomorfos na cerâmica da Idade do Ferro no NW Peninsular: inventário, cronologias e significado Nuno Oliveira / Cristina Seoane

1163 Vasos gregos em Portugal: diferentes maneiras de contar a história do intercâmbio cultural na Idade do Ferro

Daniela Ferreira

1175 Os exotica da necrópole da Idade do Ferro do Olival do Senhor dos Mártires (Alcácer do Sal) no seu contexto regional

Francisco B. Gomes

\section{Antiguidade Clássica e Tardia}

1191 O uso de madeira como combustível no sítio da Quinta de Crestelos (Baixo Sabor): da Idade do Ferro à Romanização Filipe Vaz / João Tereso / Sérgio Simões Pereira / José Sastre / Javier Larrazabal Galarza / Susana Cosme / José António Pereira / Israel Espi

1207 Cultivos de Época Romana no Baixo Sabor: continuidade em tempos de mudança? João Pedro Tereso / Sérgio Simões Pereira / Filipe Santos / Luís Seabra / Filipe Vaz

1221 A casa romana na Hispânia: aplicação dos modelos itálicos nas províncias ibéricas Fernanda Magalhães / Diego Machado / Manuela Martins

1235 As pinturas murais romanas da Rua General Sousa Machado, n. ${ }^{5}$ 1, Chaves José Carvalho

1243 Trás do Castelo (Vale de Mir, Pegarinhos, Alijó) - Uma exploração agrícola romana do Douro

Tony Silvino / Pedro Pereira

1255 A sequência de ocupação no quadrante sudeste de Bracara Augusta: as transformações de uma unidade doméstica Lara Fernandes / Manuela Martins

1263 Os Mosaicos com decoração geométrica e geométrico-vegetalista dos sítios arqueológicos da área do Conuentus Bracaraugustanus. Novas abordagens quanto à conservação, restauro, decoração e datação Maria de Fátima Abraços / Licínia Wrench

1277 “Casa Romana” do Castro de São Domingos (Cristelos, Lousada): Escavação, Estudo e Musealização Paulo André de P. Lemos

1291 A arqueobotânica no Castro de Guifões (Matosinhos, Noroeste de Portugal): O primeiro estudo carpológico

Luís Seabra / Andreia Arezes / Catarina Magalhães / José Varela / João Pedro Tereso 
1305 Um Horreum Augustano na Foz do Douro (Monte do Castelo de Gaia, Vila Nova de Gaia) Rui Ramos

1311 Ponderais romanos na Lusitânia: padrões, formas, materiais e contextos de utilização Diego Barrios Rodríguez

1323 Um almofariz centro-itálico na foz do Mondego

Marco Penajoia

1335 Estruturas romanas de Carnide - Lisboa Luísa Batalha / Mário Monteiro / Guilherme Cardoso

1347 O contexto funerário do sector da "necrópole NO" da Rua das Portas de S. Antão (Lisboa): o espaço, os artefactos, os indivíduos e a sua interconectividade na interpretação do passado Sílvia Loja, José Carlos Quaresma, Nelson Cabaço, Marina Lourenço, Sílvia Casimiro, Rodrigo Banha da Silva, Francisca Alves-Cardoso

${ }_{1361}$ Povoamento em época Romana na Amadora - resultados de um projeto pluridisciplinar Gisela Encarnação / Vanessa Dias

1371 A Arquitectura Residencial em Mirobriga (Santiago do Cacém): contributo a partir de um estudo de caso Filipe Sousa / Catarina Felício

${ }_{1385}$ O fim do ciclo. Saneamento e gestão de resíduos nos edifícios termais de Mirobriga (Santiago do Cacém)

Catarina Felício / Filipe Sousa

1399 Balsa, Topografia e Urbanismo de uma Cidade Portuária Vítor Silva Dias / João Pedro Bernardes / Celso Candeias / Cristina Tété Garcia

1413 No Largo das Mouras Velhas em Faro (2017): novas evidências da necrópole norte de Ossonoba e da sua ocupação medieval Ricardo Costeira da Silva / Paulo Botelho / Fernando Santos / Liliana Nunes

1429 Instrumentos de pesca recuperados numa fábrica de salga em Ossonoba (Faro) Inês Rasteiro / Ricardo Costeira da Silva / Paulo Botelho

1439 A Necrópole Romana do Eirô, Duas Igrejas (Penafiel): intervenção arqueológica de 2016 Laura Sousa / Teresa Soeiro

1457 Ritual, descarte ou afetividade? A presença de Canis lupus familiaris na Necrópole Noroeste de Olisipo (Lisboa)

Beatriz Calapez Santos / Sofia Simões Pereira / Rodrigo Banha da Silva / Sílvia Casimiro / Cleia Detry / Francisca Alves Cardoso

1467 Dinâmicas económicas em Bracara na Antiguidade Tardia Diego Machado / Manuela Martins / Fernanda Magalhães / Natália Botica

1479 Cerâmicas e Vidros da Antiguidade Tardia do Edifício sob a Igreja do Bom Jesus (Vila Nova de Gaia) Joaquim Filipe Ramos

1493 Novos contributos para a topografia histórica de Mértola no período romano e na Antiguidade Tardia Virgílio Lopes

\section{8. Época Medieval}

1511 Cerâmicas islâmicas no Garb setentrional "português": algumas evidências e incógnitas Constança dos Santos / Helena Catarino / Susana Gómez / Maria José Gonçalves / Isabel Inácio / Gonçalo Lopes / Jacinta Bugalhão / Sandra Cavaco / Jaquelina Covaneiro / Isabel Cristina Fernandes / Ana Sofia Gomes 
1525 Contributo para o conhecimento da cosmética islâmica, em Silves, durante a Idade Média Rosa Varela Gomes

1537 Yábura e o seu território - uma análise histórico-arqueológica de Évora entre os séculos VIII-XII José Rui Santos

1547 A encosta sul do Castelo de Palmela - resultados preliminares da escavação arqueológica Luís Filipe Pereira / Michelle Teixeira Santos

1559 A igreja de São Lourenço (Mouraria, Lisboa): um conjunto de silos e de cerâmica medieval islâmica

Andreia Filipa Moreira Rodrigues

1571 O registo material de movimentações populacionais no Médio Tejo, durante os séculos XII-XIII. Dois casos de "sunken featured buildings", nos concelhos de Cartaxo e Torres Novas Marco Liberato / Helena Santos / Nuno Santos

1585 O nordeste transmontano nos alvores da Idade média. Notas para reflexão Ana Maria da Costa Oliveira

1601 Sepulturas escavadas na rocha do Norte de Portugal e do Vale do Douro: primeiros resultados do Projecto SER-NPVD

Mário Jorge Barroca / César Guedes / Andreia Arezes / Ana Maria Oliveira

1619 "Portucalem Castrum Novum" entre o Mediterrâneo e o Atlântico: o estudo dos materiais cerâmicos alto-medievais do arqueossítio da rua de D. Hugo, nํ. 5 (Porto) João Luís Veloso

1627 A Alta Idade Média na fronteira de Lafões: notas preliminares sobre a Arqueologia no Concelho de Vouzela

Manuel Luís Real / Catarina Tente

1641 Um conjunto cerâmico medieval fora de portas: um breve testemunho aveirense Susana Temudo

${ }_{1651}$ Os Lóios do Porto: uma perspetiva integrada no panorama funerário da Baixa Idade Média à Época Moderna em meios urbanos em Portugal

Ana Lema Seabra

1659 O Caminho Português Interior de Santiago como eixo viário na Idade Média Pedro Azevedo

1665 Morfologia Urbana: Um exercício em torno do Castelo de Ourém André Donas-Botto / Jaqueline Pereira

1677 Intervenção arqueológica na Rua Marquês de Pombal/Largo do Espírito Santo (Bucelas, Loures)

Florbela Estêvão / Nathalie Antunes-Ferreira / Dário Ramos Neves / Inês Lisboa

1691 O Cemitério Medieval do Poço do Borratém e a espacialidade funerária na cidade de Lisboa Inês Belém / Vanessa Filipe / Vasco Noronha Vieira / Sónia Ferro / Rodrigo Banha da Silva

1705 Um Espaço Funerário Conventual do séc. XV em Lisboa: o caso do Convento de São Domingos da Cidade Sérgio Pedroso / Sílvia Casimiro / Rodrigo Banha da Silva / Francisca Alves Cardoso

\section{9. Época Moderna e Contemporânea}

1721 Arqueologia Moderna em Portugal: algumas reflexões críticas em torno da quantificação de conjuntos cerâmicos e suas inferências históricas e antropológicas Rodrigo Banha da Silva / André Bargão / Sara da Cruz Ferreira

1733 Faianças de dois contextos entre os finais do século XVI e XVIII do Palácio dos Condes de Penafiel, Lisboa

Martim Lopes / Tomás Mesquita 
1747 Um perfil de consumo do século XVIII na foz do Tejo: O caso do Mercado da Ribeira, Lisboa Sara da Cruz Ferreira / Rodrigo Banha da Silva / André Bargão

1761 Os Cachimbos dos Séculos XVII e XVIII do Palácio Mesquitela e Convento dos Inglesinhos (Lisboa)

Inês Simão / Marina Pinto / João Pimenta / Sara da Cruz Ferreira / André Bargão / Rodrigo Banha da Silva

1775 "Tomar os fumos da erua que chamão em Portugal erua sancta». Estudo de Cachimbos provenientes da Rua do Terreiro do Trigo, Lisboa

Miguel Martins de Sousa / José Pedro Henriques / Vanessa Galiza Filipe

1787 Cachimbos de Barro Caulínitico da Sé da Cidade Velha (República de Cabo Verde)

Rodrigo Banha da Silva / João Pimenta / Clementino Amaro

1801 Algumas considerações sobre espólio não cerâmico recuperado no Largo de Jesus (Lisboa) Carlos Boavida

1815 Adereços de vidro, dos séculos XVI-XVIII, procedentes do antigo Convento de Santana de Lisboa (anéis, braceletes e contas)

Joana Gonçalves / Rosa Varela Gomes / Mário Varela Gomes

1837 Da ostentação, luxo e poder à simplicidade do uso quotidiano: arqueologia e simbologia de joias e adornos da Idade Moderna Portuguesa Jéssica Iglésias

1849 Os amuletos em Portugal - dos objetos às superstições: o coral vermelho Alexandra Vieira

1865 Cerâmicas de Vila Franca de Xira nos séculos XV e XVI Eva Pires

1879 «Não passa por teu o que me pertence». Marcas de individualização associadas a faianças do Convento de Nossa Senhora de Aracoeli, Alcácer do Sal Catarina Parreira / Íris Fragoso / Miguel Martins de Sousa

1891 Cerâmica de Leiria: alguns focos de produção

Jaqueline Pereira / André Donas-Botto

1901 Os Fornos na Rua da Biquinha, em Óbidos Hugo Silva / Filipe Oliveira

1909 A casa de Pêro Fernandes, contador dos contos de D. Manuel I: o sítio arqueológico da Silha do Alferes, Seixal (século XVI) Mariana Nunes Ferreira

1921 O Alto da Vigia (Sintra) e a vigilância e defesa da costa Alexandre Gonçalves / Sandra Santos

1937 O contexto da torre sineira da Igreja de Santa Maria de Loures Paulo Calaveira / Martim Lopes

1949 A Necrópole do Hospital Militar do Castelo de São Jorge e as práticas funerárias na Lisboa de Época Moderna Susana Henriques / Liliana Matias de Carvalho / Ana Amarante / Sofia N. Wasterlain

1963 SAND - Sarilhos Grandes Entre dois Mundos: o adro da Igreja e a Paleobiologia dos ossos humanos recuperados

Paula Alves Pereira / Roger Lee Jesus / Bruno M. Magalhães

1975 Expansão urbana da vila de Cascais no século XVII e XVIII: a intervenção arqueológica na Rua da Vitória no 15 a 17

Tiago Pereira / Vanessa Filipe

1987 Novos dados para o conhecimento do Urbanismo de Faro em época Moderna Ana Rosa 
1995 Um exemplo de Arqueologia Urbana em Alcoutim: o Antigo Edifício dos CTT Marco Fernandes / Marta Dias / Alexandra Gradim / Virgílio Lopes / Susana Gómez Martínez

2007 Palácio dos Ferrazes (Rua das Flores/Rua da Vitória, Porto): a cocheira de Domingos Oliveira Maia

Francisco Raimundo

2021 As muitas vidas de um edifício urbano: História, Arqueologia e Antropologia no antigo Recreatório Paroquial de Penafiel Helena Bernardo / Jorge Sampaio / Marta Borges

2035 O convento de Nossa Senhora da Esperança de Ponta Delgada: o contributo da arqueologia para o conhecimento de um monumento identitário João Gonçalves Araújo / N’Zinga Oliveira

2047 Arqueologia na ilha do Corvo... em busca da capela de Nossa Senhora do Rosário Tânia Manuel Casimiro / José Luís Neto / Luís Borges / Pedro Parreira

2059 Perdidos à vista da Costa. Trabalhos arqueológicos subaquáticos na Barra do Tejo Jorge Freire / José Bettencourt / Augusto Salgado

2071 Arqueologia marítima em Cabo Verde: enquadramento e primeiros resultados do projecto CONCHA

José Bettencourt / Adilson Dias / Carlos Lima / Christelle Chouzenoux / Cristóvão Fonseca / Dúnia Pereira / Gonçalo Lopes / Inês Coelho / Jaylson Monteiro / José Lima / Maria Eugénia Alves / Patrícia Carvalho / Tiago Silva

2085 Trabalhos arqueológicos na Cidade Velha (Ribeira Grande de Santiago, Cabo Verde): reflexões sobre um projecto de investigação e divulgação patrimonial André Teixeira / Jaylson Monteiro / Mariana Mateus / Nireide Tavares / Cristovão Fonseca / Gonçalo C. Lopes / Joana Bento Torres / Dúnia Pereira / André Bargão / Aurélie Mayer / Bruno Zélie / Carlos Lima / Christelle Chouzenoux / Inês Henriques / Inês Pinto Coelho / José Lima / Patrícia Carvalho / Tiago Silva

2103 A antiga fortificação de Quelba / Khor Kalba (E.A.U.). Resultados de quatro campanhas de escavações, problemáticas e perspectivas futuras Rui Carita / Rosa Varela Gomes / Mário Varela Gomes / Kamyar Kamyad

2123 Colónias para homens novos: arqueologia da colonização agrária fascista no noroeste ibérico Xurxo Ayán Vila / José Mạ . Señorán Martín 


\title{
ANÁLISE FUNCIONAL DE MATERIAL LÍTICO EM SÍLEX DO CASTRO DE VILA NOVA DE S. PEDRO (AZAMBUJA, PORTUGAL): UMA PRIMEIRA ABORDAGEM
}

\author{
Rafael Lima ${ }^{1}$
}

\begin{abstract}
RESUMO
A realização de uma análise traceológica de parte do espólio de peças em sílex do castro de Vila Nova de S. Pedro vem, por um lado, indicar a possibilidade de realizar uma análise funcional sobre uma parte mais abrangente do espólio recolhido, ainda que com algumas ressalvas, e, por outro, colocar em evidência a importância de certas actividades no plano económico, ainda que se trate de uma análise preliminar.

Observa-se, para já, a importância das actividades agrícolas, através do emprego de peças para o corte de matérias vegetais/cereais, assim como o emprego de pontas de seta como pontas de projécteis. Observa-se, também, a reutilização das peças através de processos de reavivamento, o que permite, juntamente com os restantes dados funcionais, a realização de certas inferências e questões acerca dos processos económicos e comportamentais das populações que habitaram o castro de Vila Nova de S. Pedro.
\end{abstract}

Palavras-chave: Análise funcional, Calcolítico, Castro de Vila Nova de S. Pedro.

\begin{abstract}
The conduction of a traceological analysis on a part of the collection of flint tools from the Vila Nova de S. Pedro castro allows, for one part, to demonstrate the feasibility to perform a functional analysis over a wider portion of the gathered materials, although with some caveats, and, on the other, place in evidence the importance of certain activities on the economical field, even though it is a preliminary analysis.

It is observed, for now, the importance of agricultural practices, trough the employment of tools to cut soft vegetable matter/cereals, as well as the employment of arrow points as projectile tips. It is also observed the reutilization of tools trough processes of edge revival, which allows, together with the rest of the functional data, the realization of certain inferences and questions about the economic processes and the behaviour of the populations which inhabited the Vila Nova de S. Pedro castro.

Keywords: Functional analysis, Chalcolithic, Castro of Vila Nova de S. Pedro.
\end{abstract}

\section{INTRODUÇÃO}

Poucos sítios alcançam, no séc. XX, em Portugal, a importância atingida a nível internacional que o castro de Vila Nova de S. Pedro granjeou. Intervencionado primeiramente por Afonso do Paço e Eugénio Jalhay, torna-se, para o período Calcolítico, um dos sítios de referência para o seu estudo e compreensão (Jalhay et Paço, 1945). Povoado muralhado, com um extenso espólio recolhido, algum de grande qualidade, obteve (e obtém) honras de ser um dos ex libris do museu arqueológico do Carmo, em Lisboa, onde toda uma sala lhe é dedicado, atestando assim a sua importância não só no plano nacional, mas também internacional, como destaque da Pré-história recente da fachada oeste da península Ibérica (Arnaud et Gonçalves, 1990, 1995). O interesse por este sítio não permaneceria somente no séc. XX, estando actualmente em curso um novo e abrangente projecto de investigação, impulsionado, novamente, pela Associação dos Arqueólogos Portugueses (Arnaud et al., 2017).

Do total do espólio recolhido no povoado advém uma importante e variada resenha científica, no qual 
é evidente a procura pela identificação das actividades económicas aí praticadas. Se, por um lado, o volume já disponível de informação permite reconstituir parcialmente o quotidiano vivido no povoado, a ausência de estudos funcionais para os artefactos de sílex, com uma metodologia apropriada para a sua análise, constitui um potencial por explorar para uma melhor compreensão do plano económico e comportamental do castro de Vila Nova de S. Pedro. Esse potencial é o que se pretende explorar com este estudo. O presente estudo tem, então, três ordens. Numa primeira ordem, verificar a possibilidade de aplicação de uma análise traceológica no conjunto, ou seja, verificar, através do estudo de parte do total desse espólio qual o grau de preservação dos vestígios de uso no conjunto de peças em sílex e verificar a sua adequação à realização de um estudo traceológico que sirva de primeira abordagem para a realização de uma análise numa maior percentagem do total do conjunto. Numa segunda ordem, caso se observe a possibilidade da realização de uma análise traceológica, procurar observar e identificar os dados que permitam inferir acerca do uso e função das peças. Através disso, já numa terceira ordem, aludir acerca do plano económico e comportamental destas populações, ainda que se trate de dados preliminares tendo em conta o volume do conjunto estudado face ao total de espólio que constitui o acervo de peças em sílex do castro de Vila Nova de S. Pedro.

\section{MATERIAIS E METODOLOGIA}

Para o presente estudo foram analisadas 46 peças, de sílex, provenientes da intervenção de Afonso do Paço no castro de Vila Nova de S. Pedro (1937-1967): 10 lamelas, 16 pontas de seta, um núcleo, uma lâmina, sete lâminas retocadas, um furador, um fragmento retocado, um raspador, duas raspadeiras e seis lâminas ovóides. A escolha do material estudado recaiu na procura de um grupo tipologicamente distinto, de forma a evitar a ausência de certos usos/funções que possam estar restringidos a determinadas tipologias. O procedimento analítico seguiu o protocolo comumente empregue para este tipo de análises, conforme introduzido por Semenov (1964) e posteriormente desenvolvido por Keeley (1980) e Plisson (1985), entre muitos outros. As peças foram primeiramente observadas através da lupa binocular (Leica DMS 100o) para identificar potenciais zonas activas (e.g. levantamentos de impacto e fracturas) e poste- riormente recorreu-se ao microscópio metalográfico (Leica DM250o MH) de forma a observar os vestígios microscópios de uso (e. g. micropolidos e estrias). O registo fotográfico foi obtido através de máquina fotográfica (Leica ICC50 W) acoplada ao microscópio metalográfico.

Através de uma série de inferências procurou distinguir-se entre peças usadas e não usadas, assim como as respectivas zonas activas, identificar a cinemática de trabalho, determinar a matéria trabalhada (esta somente quando distinguível), a intensidade de utilização do utensílio e ainda o possível reaproveitamento das peças através de processos de reavivamento e reutilização, caso esta fosse uma realidade observável neste conjunto.

\section{RESULTADOS}

A análise funcional sobre as 46 peças estudadas trouxe alguns resultados acerca do estado de preservação dos vestígios de uso e acerca da cinemática de trabalho e das matérias trabalhadas, conforme pode ser observado na Tabela 1, e apresentado com maior descrição adiante.

\subsection{Estado de conservação dos vestígios de uso}

$O$ presente conjunto encontra-se, no seu geral, em bom estado de conservação, podendo analisar-se as peças com relativa facilidade (Figura 1), tendo em conta a boa preservação das superfícies e dos bordos das peças. Contudo, algumas peças apresentam alguns aspectos que dificultam/impossibilitam a sua análise, tais como a presença de tratamento térmico e/ou alterações pós-deposicionais (Figura 2), o que inviabiliza dessa forma a correcta aferição dos potenciais traços diagnósticos de uso, conforme referido por alguns estudos (vide e.g. Levi-Sala, 1986a, 1986b e Gutierrez Saez et al., 1988). Estas ocorrências (especialmente observáveis na generalidade das lamelas) incluem alterações térmicas, alterações pós-deposicionais como aplicação de verniz, entre outras, apresentando-se as superfícies e os bordos bastante afectados.

\subsection{Vestígios de uso}

Das 46 peças estudadas 11 apresentaram traços de uso conducentes à identificação da actividade para que foram empregues. As peças que evidenciaram utilização são duas lâminas ovóides, cinco lâminas retocadas e quatro pontas de seta. 
Tanto as lâminas ovóides (Figura 3) quanto as lâminas retocadas (Figura 4) foram utilizadas para cortar matéria vegetal macia, provavelmente cereais, empregando somente um dos gumes como ponto de contacto com a matéria a trabalhar. A presença de tratamento térmico em várias das lâminas ovóides dificultou a análise dessas peças.

Já as pontas de seta apresentam fracturas diagnósticas de impacto (FDI) que induzem ao seu emprego enquanto pontas de projéctil (Figura 5).

\section{RESULTADOS/DISCUSSÃO}

O presente conjunto refere-se a uma muito pequena percentagem do total do inventário da indústria lítica do povoado calcolítico de Vila Nova de S. Pedro, constituído por milhares de artefactos agrupados em diferentes categorias tipológicas. Tendo isso em atenção, podem, mesmo assim, retirar-se alguns dados que poderão facultar um melhor entendimento acerca do modo de vida destas populações, especialmente no que toca à gestão da matéria-prima, assim como levantar outras problemáticas.

Relativamente ao grau de conservação das peças este revela-se algo problemático. Se, por um lado, observa-se uma leitura facilitada de certas peças, principalmente devido à formação de polidos característicos como os observados para o corte de cereais evidenciado nas lâminas ovóides e nas retocadas (vide Figura 3 e Figura 4), por outro lado o grau de preservação de outras peças dificultam a sua leitura pelos factos já referidos anteriormente (vide Figura 2).

Destes aspectos destacam-se as alterações térmicas e as alterações pós-deposicionais, especialmente a colocação de verniz e tinta que prejudica qualquer leitura funcional sobre as peças. Relativamente às alterações térmicas, estas dificultam a leitura das peças, não a inviabilizando, contudo, totalmente, conforme nos afirmam alguns estudos previamente publicados (Clemente, 1995, 1997 e Gibaja e Clemente, 1997). Ainda assim, como esses mesmos estudos afirmam, as alterações térmicas dificultam mais a observação dos traços de uso em matérias moles de origem natural, o que não é o caso do corte em matéria vegetal/cereais presente neste estudo, o que não invalida, contudo, a possibilidade de menor observação dos traços de uso nestas peças.

Observa-se, no entanto, no que toca à preservação dos traços de uso, o apagamento intencional das provas dessa mesma utilização. Este "apagamento" voluntário resulta, como se pode observar na Figura 4-1A, da prática de reavivamento dos gumes para um uso continuado das peças, obtendo, dessa forma, um maior tempo de vida útil do utensílio. Esta prática de reaproveitamento das peças através do reavivamento dos gumes não aparenta ser um acto incomum tendo em conta o número de lâminas retocadas com esses indícios (3/7) - paragem abrupta do polido, presença de polido nas arestas mais elevadas das áreas retocadas e ausência nas áreas menos elevadas e presença de polido ao longo do reverso da área retocada. O facto de terem sido reavivadas reduz a leitura das peças não sendo possível em certos casos observar o grau de desenvolvimento dos traços de uso o que dificulta a observação do tempo de uso destes utensílios (agravado pelo facto de terem sofrido alterações térmicas, intencionais ou não). Apesar disso, o próprio reavivamento permite considerar que as peças teriam um desgaste suficiente que levaria à necessidade dessa acção.

Quanto à forma de emprego das peças analisadas, a ausência de certos dados como estrias, alguns tipos de micropolidos e esquirolamentos não permitem inferir acerca de algumas hipóteses tais como formas e materais de encabamento ou o seu manuseamento. Contudo, consegue observar-se que, pelo menos ao nível do uso em matéria vegetal/cereais, somente um dos gumes teria sido empregue para tal, observando-se como tal só uma frente activa nessas peças, tendo em conta a total ausência de polido e outros factores tais como estrias e microesquirolamentos típicos de uso nos restantes gumes.

Também relativamente ao emprego das pontas de flechas, o posicionamento do tipo de fracturas observado, a própria tipologia das peças e um aparente maior desgaste na parte inferior das mesmas permite com alguma segurança considerar o seu uso na forma vertical. Estas teriam dessa forma ter de ter sido encabadas ou na extremidade proximal ou ao longo do seu eixo mantendo a verticalidade da peça além da extremidade distal livre como ponto de impacto. Já o motivo da sua recuperação após serem usadas não é claro, podendo estar relacionada com práticas de reutilização como já avançado para as lâminas retocadas. A ausência de dados não permite mais do que criar essa suposição.

Observando as actividades postas em evidência pela análise funcional observa-se uma prática agrícola que não se encontra restringida a nível tipológico, mais precisamente o corte de cereais/matéria ve- 
getal macia, servindo, provavelmente, como foices. Esta prática estende-se não só pelas lâminas retocadas, mas, também, pelas lâminas ovóides. No entanto, não surgem dados que permitam supôr se se tratam de utensílios empregues indiscriminadamente para o corte de matéria vegetal macia/cereais ou se há diferenças no seu uso conforme os sugeridos pelo estudo de Clemente Conte et al. (2018) relativamente à posição de corte e à maturidade da matéria recolhida, ou que reflitam as espécies referidas por Afonso do Paço (1954) que seriam cultivadas nas proximidades do sítio.

A nível nacional o emprego das lâminas ovóides como foices tem, contudo, paralelo nos sítios da $\mathrm{Pa}$ rede e do Alto do Estoril (Igreja, 2010), assim como no castro de Chibanes (Clemente-Conte et al., 2014). Deve ter-se em atenção que o número de peças analisadas em ambos os estudos e com traços de uso registados são quase tão reduzidos quanto no presente estudo, muitas das quais se encontrem com alterações inviabilizando a sua leitura como sucede em $\mathrm{Pa}$ redes e no Alto do Estoril (Igreja, 2010), pelo que se deve ter em conta tais dados aquando da realização de conclusões acerca destes sítios. Já o uso de lâminas retocadas para o corte de cereais é observado no actual território português desde o Neolítico Antigo como comprovado, por exemplo, através do sítio de Cortiçóis (Carvalho et al., 2013). Já o seu emprego em trilhos e não só foices é visível no sítio de Chibanes (Clemente Conte et al., 2014), podendo encontrar paralelos muito semelhantes, por exemplo, em Espanha, no sítio de El Casetón de la Era, Valladolid (Gibaja et al., 2012). O uso como parte de trilho não é, contudo, ainda observável em Vila Nova de S. Pedro, não se excluindo a possibilidade de ser observado noutras peças ainda não estudadas.

Já o uso das pontas de seta aparenta estar virado, como expectável, para instrumentos de impacto, tendo em conta os traços diagnósticos, ainda que a ausência de dados como estrias e polidos não permita identificar em que matéria foram empregues. Não foram identificados outros usos, como por exemplo os referidos por Igreja para Paredes e Alto do Estoril para os raspadores (Igreja, 2010), nem os referidos por Amaro (ainda que utilizando uma metodologia insuficiente para a análise por ele pretendida), de desbaste e corte de carcaças e peles de animais para as lâminas ovóides de Vila Nova de S. Pedro (Amaro, 2004/2005). Esta ausência de outros usos deve ser, contudo, desvalorizada, tendo em conta o reduzido número de peças estudadas, sendo possível que surjam eventualmente noutras peças ainda não analisadas.

Observado então a gestão da utensilagem, não nos permitindo os dados, tendo em conta o reduzido volume de peças estudadas, fazer mais do que estas breves observações, possibilita-nos, contudo, ponderar sobre algumas questões acerca do acervo lítico de Vila Nova de S. Pedro.

Assim sendo, surge, primeiramente a questão da produção e reaproveitamento das peças. Trata-se do tratamento térmico uma técnica generalizada para a produção destas peças numa primeira parte ou constituirá novamente uma necessidade para o reavivamento das peças? De que forma pode influenciar o tratamento térmico na produção de traços de uso, principalmente tendo em conta para as actividades observadas no castro de Vila Nova de S. Pedro (corte de matéria vegetal macia/cereais)? Qual a necessidade de reavivamento dos gumes? Estaremos perante uma tentativa de contenção de escassez de matéria-prima? $\mathrm{Ou}$, pelo contrário, uma procura da manutenção do volume de matéria-prima de forma a evitar/diminuir uma possível ruptura de stock através de uma economização dos utensílios ou ainda uma simples procura de rentabilização da utensilagem? Seria essa reutilização o justificativo da recuperação das pontas de seta? Seria, também, o reavivamento um gesto expedito por parte do utilizador de forma a prosseguir o trabalho, no caso do uso das foices por exemplo, realizado por quem usa o instrumento, ou parte maior da gestão da utensilagem lítica do povoado? Somente um estudo mais abrangente poderá ou não procurar responder a tal.

\section{CONCLUSÃO}

Podemos constactar que o presente estudo mais não apresenta do que dados preliminares acerca dos traços de uso conservados na indústria lítica do povoado calcolítico de Vila Nova de S. Pedro. Destes dados preliminares concluem-se, essencialmente, três pontos. O primeiro trata da possibilidade de realização a uma maior escala da traceologia para o estudo dos materiais líticos em sílex, atendendo, contudo, a alguns pontos já explicitados. O segundo é o emprego de algumas tipologias para o corte de matéria vegetal macia/cereais, mais especificamente lâminas retocadas e lâminas ovóides, que têm, como já referido, paralelos a nível nacional. O terceiro, refe- 
rente à gestão e acções de descarte/reaproveitamento, surge o reaproveitamento destas peças através de acções de reavivamento dos gumes que poderão estender-se não só às lâminas retocadas mas, também a outros grupos tipológicos, não estando, contudo, ainda verificado.

Ainda que não pareça existir qualquer escassez de matéria-prima ou dificuldade de acesso às suas fontes, a gestão e procura de boa matéria-prima como base da indústria de pedra lascada destas populações reverteria, como acção final, num reaproveitamento desta mesma matéria para um aumento do tempo de vida útil dos utensílios. Poderia tal servir como tentativa de diminuição/contenção de uma procura dessa mesma matéria-prima que poderia não vir com uma regularidade ou facilidade que levasse estas populações ao descarte imediato aquando do desgaste dos gumes activos ou a uma simples procura de aumento de rentabilidade das peças.

Ainda que o presente estudo mais não seja que uma nota introdutória no estudo da função dos objectos em sílex do povoado de Vila Nova de S. Pedro tendo em conta o seu reduzido volume, pode complementar-se com outros sítios os quais também já foram realizados estudos funcionais, quer existentes quer futuros, e fazer comparações, ainda que breves e circunstanciais, com outros sítios de cronologia semelhante.

\section{AGRADECIMENTOS}

O autor agradece ao Museu Arqueológico do Carmo/ Associação dos Arqueólogos Portugueses a cedência dos materiais para estudo e, em especial, ao doutor César Neves todo o auxílio prestado. Os materiais foram analisados com o equipamento da UNIARQ, à qual se agradece, também, a cedência de espaço para a realização do presente estudo. Um agradecimento especial é devido ao doutor Ignacio Clemente Conte, à professora doutora Mariana Diniz e à doutora Marina Igreja, cujos comentários foram extremamente úteis para a realização deste trabalho.

\section{BIBLIOGRAFIA}

AMARO, Gonçalo (2004/2005) - Interpretação das facas ovóides (foicinhas) através do estudo dos exemplares de Vila Nova de S. Pedro. Arqueologia \& História. Lisboa. 56/57, pp. 63-8o.

ARNAUD, José Morais \& GONÇALVES, João Ludgero Marques (1990) - A fortificação pré-histórica de Vila Nova de S. Pedro (Azambuja) - balanço de meio século de investigações. $1^{\underline{a}}$ parte. Revista de Arqueologia da Assembleia Distrital de Lisboa. Lisboa. 1, pp. 25-48.

ARNAUD, José Morais \& GONÇALVES, João Ludgero Marques (1995) - A fortificação pré-histórica de Vila Nova de S. Pedro (Azambuja) - balanço de meio século de investigações. ${ }^{2}$ parte. Revista de Arqueologia da Assembleia Distrital de Lisboa. Lisboa. 1, pp. 11-40.

ARNAUD, José Morais; DINIZ, Mariana; NEVES, César \& MARTINS, Andrea (2017) - Vila Nova de S. Pedro - de novo, no $3^{\circ}$ milénio. Um projecto para o futuro. Arqueologia e História. Lisboa. 66/67, pp. 7-17.

CARVALHO, António Faustino; GIBAJA, Juan Francisco \& CARDOSO, João Luís (2013) - Insights into the earliest agriculture of Central Portugal: Sickle implements from the Early Neolithic site of Cortiçóis (Santarém). Comptes Rendus Palevol. 12: 1, pp. 31-43.

CLEMENTE CONTE, Ignacio (1995) - Silex y Lustre Termico en el Paleolítico Medio. Alteración o Técnica de Talla? El Ejemplo de Mediona I (Alt Penedès, Barcelona). In JORGE, Vitor Oliveira, ed. - Actas do $1^{\underline{0}}$ Congresso de Arqueologia Peninsular. Porto: Sociedade Portuguesa de Antropologia e Etnologia. VIII, pp. 37-43.

CLEMENTE CONTE, Ignacio (1997) - Thermal Alterations of Flint Implements and the Conservation of Microwear Polish: Preliminary Experimental Observations. In Ramos Millá, Antonio et Bustillo, Maria Angeles, eds. - Siliceous Rocks and Culture (Monográfica Arte y Arqueología). Granada: Universidad de Granada, pp. 525-535.

CLEMENTE CONTE, Ignacio; MAZZUCCO, Niccolò \& SOARES, Joaquina (2014) - Instrumentos para siega y procesado de plantas desde el Calcolítico al Bronce antíguo de Chibanes (Palmela, Portugal). Trabajos de Prehistoria. 71: 2, pp. 330-342.

CLEMENTE CONTE, Ignacio; IBÁÑEZ ESTÉVEZ, Juan José; GIBAJA BAO, Juan Francisco; MAZZUCCO, Niccolò; TERRADAS, Xavier; MOZOTA HOLGUERAS, Millán \& BORREL, Feran (2018) - Cereal Use-Wear Traces and Harvesting Methods. In BERIUHETE AZORÍN, Marian et LOZOVSKAYA, Olga, eds. - Subsistence Strategies in the Stone Age, Direct and Indirect Evidence of Fishing and Gathering. Materials of the International Conference Dedicated to the $5^{\text {th }}$ Anniversary of Vladimir Mikhailovich Lozovski 15-18 May 2018, Saint Petersburg. São Petersburgo, pp. 192-194. 
GIBAJA, Juan Francisco; CRESPO, Manuel; DELIBES, Germán; FERNÁNDEZ, Julio; FRAILE, Cristina; HERRÁN, José Ignacio; PALOMO, Antoni \& RODRÍGUEZ, José Antonio (2012) - El uso de trillos durante la Edad del Cobre en la Meseta española. Análisis traceológico de una colección de denticulados de sílex procedentes del "recinto de fosos" de El Casetón de la Era (Villalba de los Alcores, Valladolid). Trabajos de Prehistoria. 69: 1, pp. 133-148.

GIBAJA, Juan Francisco \& CLEMENTE, Ignacio (1997) - El tratamento térmico del sílex y sus repercusiones en la determinación de los rastros de uso. Algunos ejemplos del neolítico en Cataluña. Revista de Arqueología de Ponent. Lleida: Universidad de Lleida. 7, pp. 153-16o.

GUTIERREZ SAEZ, Carmen; GONZALEZ URQUIJO, Jesus Emilio \& IBÁÑEZ ESTÉVEZ, Juan José (1988) - Alteraciones microscópicas en el tratamento convencional del material lítico: su incidencia en las huellas de uso. MUNIBE (Antropologia y Arqueologia). San Sebastian: Sociedad de Ciencias Aranzadi, Suplemento 6, pp. 83-89.

IGREJA, Marina (2010) - Estudo traceológico dos furadores e lâminas ovóides do Alto do Estoril e da Parede: resultados sobre a função e o modo de funcionamento destas peças. In Gonçalves, Victor S. et SOUSA, Ana Catarina, eds. - Transformação e Mudança no Centro e Sul de Portugal: o $4^{0}$ e o $3^{\circ}$ milénios a.n.e. Actas do Colóquio Internacional (Cascais, 4-7 Outubro 2005). Cascais: Câmara Municipal, pp. 206-211.
JALHAY, Eugénio \& PAÇO, Afonso do (1945) - El Castro de Vilanova de San Pedro. In Actas y Memorias de la Sociedad Espanola de Antropologia, Etnografia y Prehistoria. Madrid: Museo Antropológico Nacional. XX, pp. 5-93.

KEELEY, Lawrence (1980) - Experimental Determination of Stone Tool Uses. Chicago: University of Chicago Press.

LEVI-SALA, Irene (1986a) - Experimental replication of post-depositional surface modification on flint”. Early Man News. Newsletter of Uman Palaeoecology. Tübingen: Archaeologica Venatoria. 9/10/11, pp. 103-110.

LEVI-SALA, Irene (1986b) - Use wear and post-depositional surface modification: a word of caution. Journal of Archaeological Science. Londres: Elsevier. 13, pp. 229-244.

PAÇO, Afonso do (1958) - Sementes pré-históricas do Castro de Vila Nova de S. Pedro. In Anais. Lisboa: Academia Portuguesa da História. Série II. 5, separata pp. 281-359.

PLISSON, Hugues (1985) - Etude fonctionelle d'outillages lithiques préhistoriques par l'analyse des micro-useres: recherche méthodologique et archéologique. Dissertação de Doutoramento apresentado à Universidade de Paris I.

SEMENOV, Sergej Aristarchovic (1964) - Prehistoric Technology. An Experimental Study of the oldest Tools and Artefacts from traces of Manufacture and Wear. Londres: Cory, Adams \& Mackay.

\begin{tabular}{|c|c|c|c|c|c|c|c|c|}
\hline \multirow{3}{*}{ Tipologia } & \multirow{3}{*}{$\begin{array}{c}\text { Peças } \\
\text { analisadas }\end{array}$} & \multicolumn{4}{|c|}{ Estado de conservação } & \multicolumn{3}{|c|}{$\begin{array}{l}\text { Cinemática de trabalho e } \\
\text { matérias trabalhadas }\end{array}$} \\
\hline & & \multirow[b]{2}{*}{ Analisável } & \multirow{2}{*}{$\begin{array}{c}\text { Sem } \\
\text { vestígios } \\
\text { de uso }\end{array}$} & \multirow{2}{*}{$\begin{array}{c}\text { Com } \\
\text { vestígios } \\
\text { de uso }\end{array}$} & \multirow{2}{*}{$\begin{array}{l}\text { Alteradas/ } \\
\text { Não } \\
\text { analisáveis }\end{array}$} & $\begin{array}{l}\text { Longitudinal } \\
\text { (corte) }\end{array}$ & Impacto & \multirow[b]{2}{*}{ Tota } \\
\hline & & & & & & $\begin{array}{l}\text { Matéria } \\
\text { vegetal }\end{array}$ & $\begin{array}{l}\text { Ponta de } \\
\text { projéctil } \\
(\text { FDI })\end{array}$ & \\
\hline Frag. retocado & 1 & 1 & 1 & - & - & - & - & - \\
\hline Furador & 1 & 1 & 1 & - & - & - & - & - \\
\hline Lamela & 10 & 2 & 2 & - & 8 & - & - & - \\
\hline Lâmina & 1 & - & - & - & 1 & - & - & - \\
\hline Lâmina ovóide & 6 & 5 & 3 & 2 & 2 & 2 & - & 2 \\
\hline Lâmina retocada & 7 & 7 & 2 & 5 & - & 5 & - & 5 \\
\hline Núcleo & 1 & 1 & 1 & - & - & - & - & - \\
\hline Ponta de seta & 16 & 14 & 10 & 4 & 2 & - & 4 & 4 \\
\hline Raspadeira & 2 & 2 & 2 & - & - & - & - & - \\
\hline Raspador & 1 & 1 & 1 & - & - & - & - & - \\
\hline Total & 46 & 34 & 23 & 11 & 13 & 7 & 4 & 11 \\
\hline
\end{tabular}

Tabela 1 - Análise funcional de espólio lítico em sílex do castro de Vila Nova de S. Pedro. 

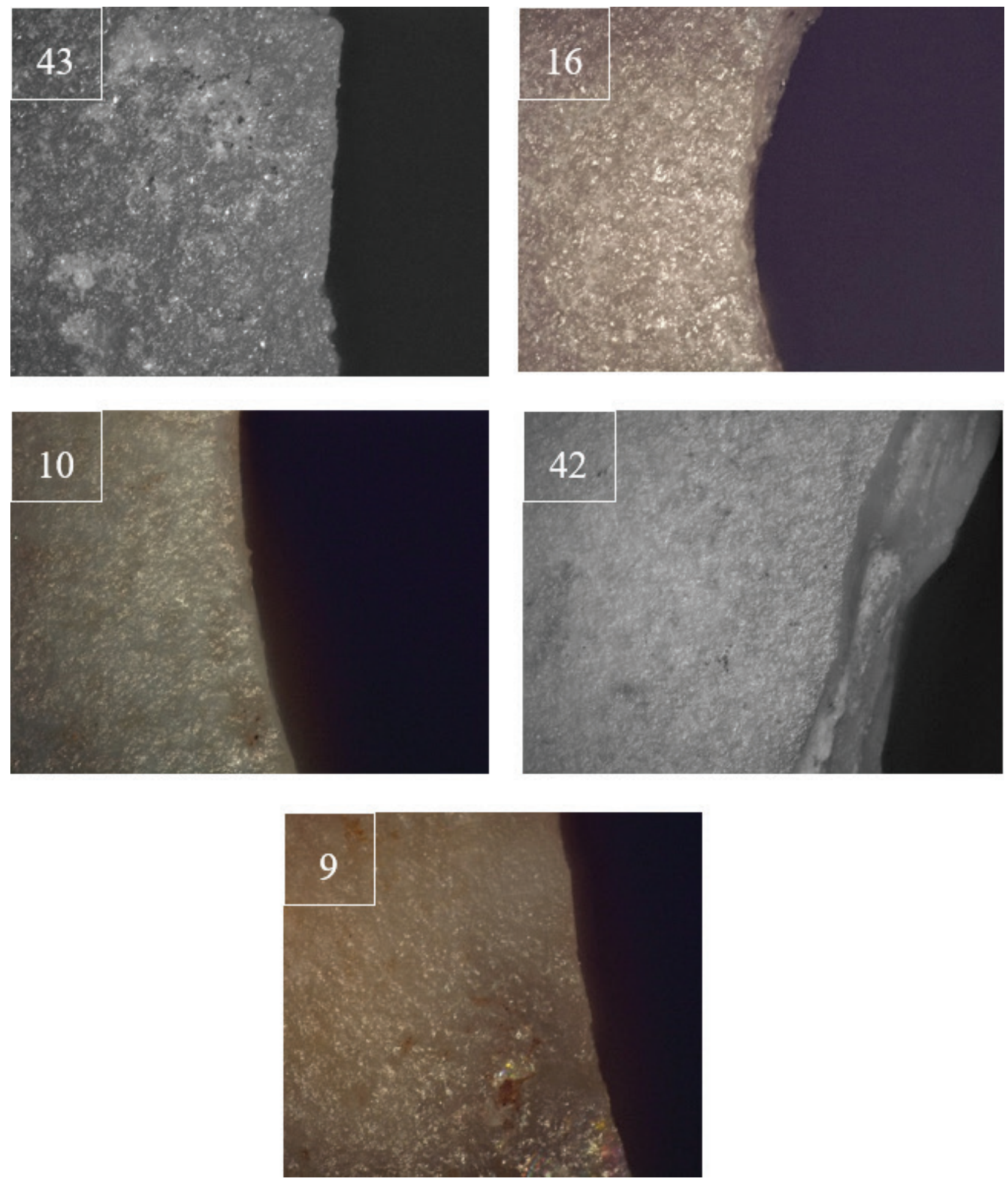

Figura 1 - Peças com bom estado de preservação das superfícies. 

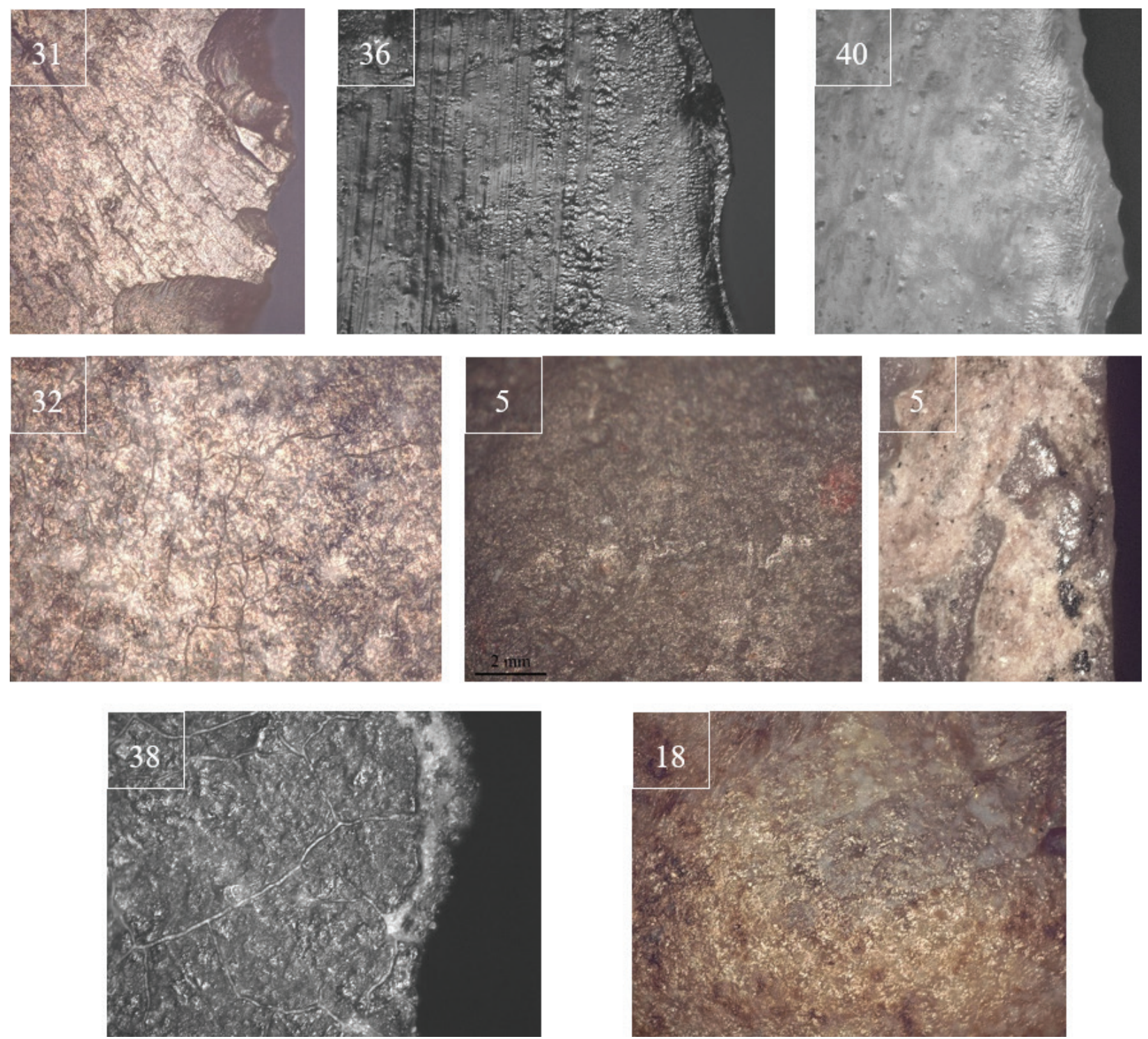

Figura 2 - Peças com inferior grau de preservação e alterações pós-deposicionais, que impossibilitam/dificultam a leitura das mesmas. Peças no 31, 32 e 38: presença de crazing; 36 e 40: verniz aplicado na peça, impossibilitando a leitura dos gumes; 5 (central): superfície da peça com alteração pós-deposicional, riscada; 5 (direita): superfície da peça riscada por grafite; 18 : queimada e com formação de patina/lustre de solo (?) (100x). 

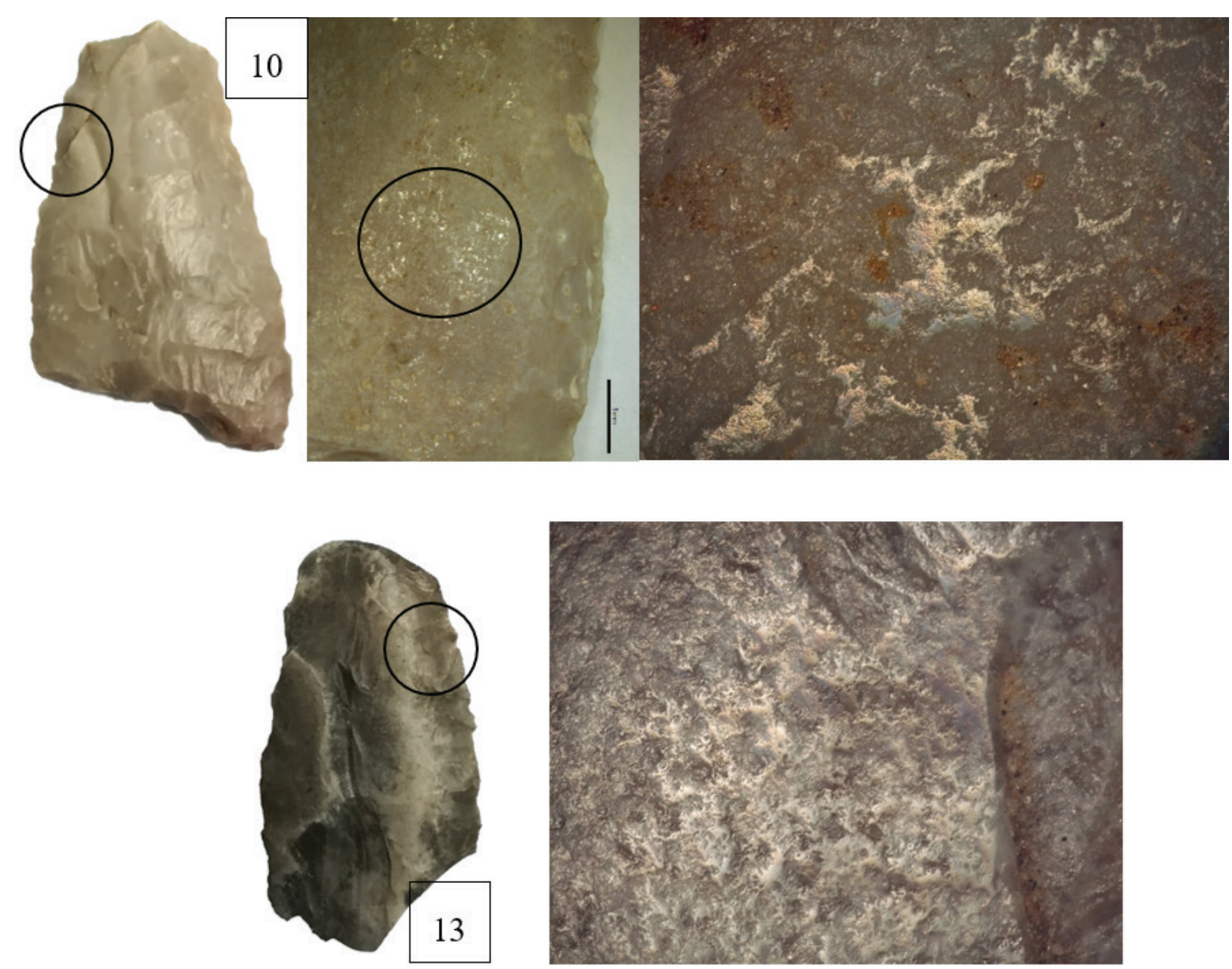

Figura 3 - Lâminas ovóides com presença de polido de matéria macia vegetal, com diferentes graus de conservação e desenvolvimento. O tratamento térmico observável na peça 13 e o facto de estar queimada prejudicaram a preservação do polido, assim como na peça 10, ainda que em menor grau. (100x). 


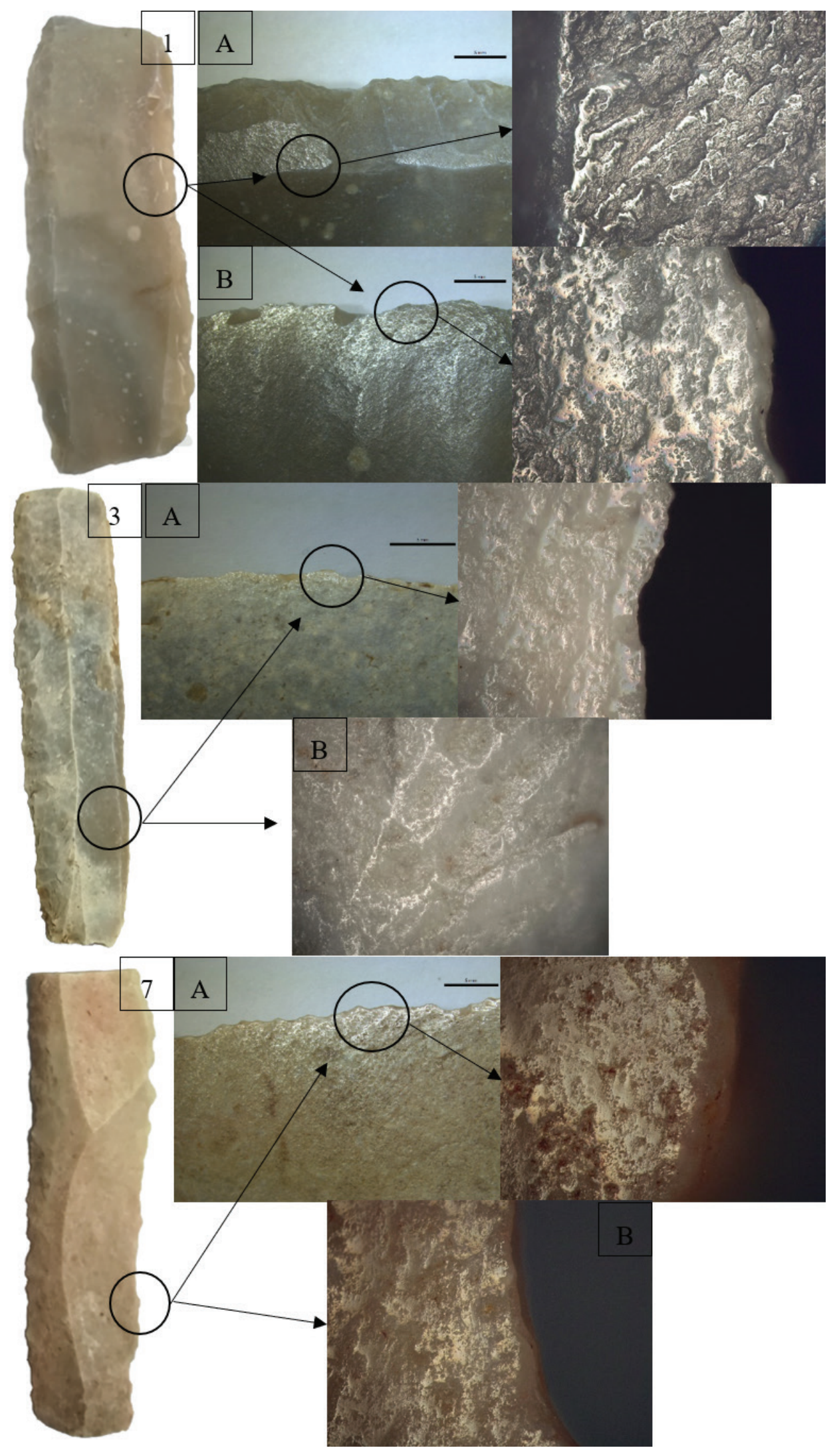

Figura 4 - Lâminas retocadas com traços de uso de corte de matéria vegetal/cereais. 1A - Lustre de corte de matéria vegetal/cereal que termina abruptamente na área retocada; $1 \mathrm{~B}$ - reverso da zona $1 \mathrm{~A} ; 3 \mathrm{~B}$ - Polido a desenvolver-se nas áreas mais elevadas; $3 \mathrm{~A}$ - polido bastante desenvolvido no reverso da mesma área; $7 \mathrm{~A}$ - Reverso e parte frontal (B) da lâmina, ambos com algum desenvolvimento do polido. (10ox). 

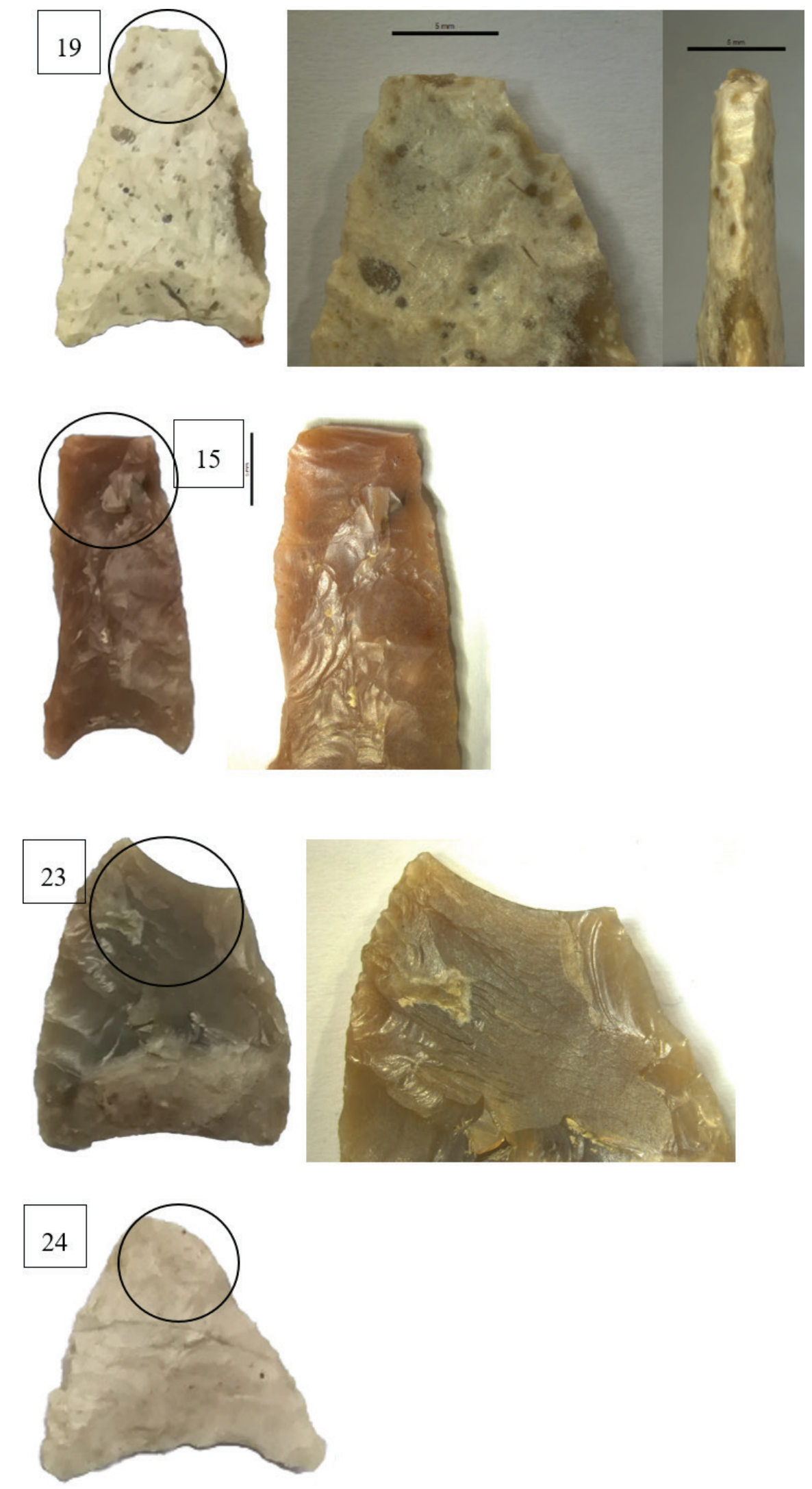

Figura 5- Pontas de flechas com fracturas diagnósticas de impacto. 19 - Vista frontal e lateral da fractura: snap terminating bending fracture com esquirolamento lateral; 1 - feather bending fracture; 23 - feather terminating bending fracture; 24 - cone initiating fracture. 


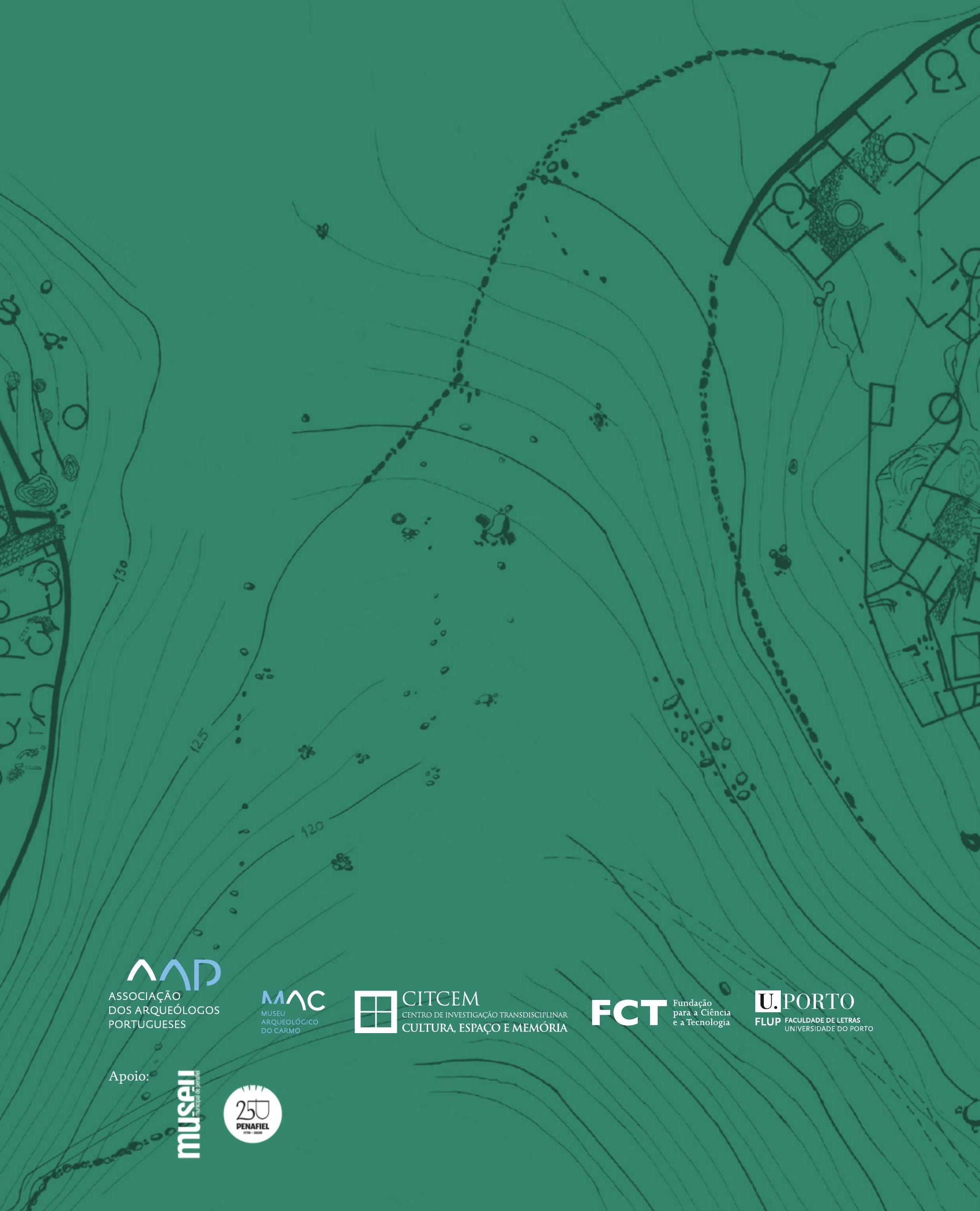

